\title{
Penyuluhan Pembuatan Jamu Kunyit Asam Dan Jamu Empon- Empon Dalam Meningkatkan Imunitas Tubuh Masyarakat Di Daerah Puskesmas Tiban Baru
}

\author{
Delladari Mayefis ${ }^{1}$ \\ ${ }^{1}$ Institut Kesehatan Mitra Bunda \\ E-mail: dellamayefis@gmail.com \\ Suci Fitriani Sammulia ${ }^{2}$ \\ ${ }^{2}$ Institut Kesehatan Mitra Bunda \\ E-mail: sucifitriani.sammulia22@gmail.com
}

\author{
Siska Widiastuti ${ }^{3}$ \\ ${ }^{3}$ Institut Kesehatan Mitra Bunda \\ E-mail: siskawidiastuti17@gmail.com \\ Dwi Puspa Meileni ${ }^{4}$ \\ ${ }^{4}$ Institut Kesehatan Mitra Bunda \\ E-mail: dwipuspameilni@gmail.com
}

\begin{abstract}
Article History:
Received: 2021-09-23

Revised: 2021-12-30

Accepted:2022-01-25

Keywords : Body immunity, Covid-19,

Traditional medicine, Jamu

Abstract: Indonesian people have experienced a decline in their immune health caused by the impact of the Covid-19 pandemic. To increase the body's immunity, one of them is using traditional medicine (jamu). The use of herbal medicine is an Indonesian ancestral heritage which is obtained empirically and from generation to generation. The method used is the manufacture of herbal medicine and counseling to the community in the Tiban Baru Public Health Center area which is one of the serious locations for handling Covid19 in increasing the community's immunity. The results show that herbal medicine is very helpful in increasing the body's immunity and all the ingredients are easily available. Participants in making herbal medicine are about 10 cadres and 5 students. The distribution of herbal preparations was given to around 30 people at the Tiban Baru Public Health Center.
\end{abstract}


Riwayat Artikel :

Diajukan: 23-09-2021

Diperbaiki: 30-12-2021

Diterima: 25-01-2022
Kata kunci : Imunitas tubuh, Covid-19, Obat tradisional, Jamu

\begin{abstract}
Abstrak: Masyarakat Indonesia mengalami penurunan kesehatan Imunitas tubuh yang disebabkan oleh dampak pandemi Covid-19. Untuk meningkatkan imunitas tubuh salah satunya yaitu menggunakan obat tradisional (jamu). Penggunaan jamu merupakan warisan nenek moyang Indonesia yang diperoleh secara empiris dan turun temurun. Metode yang digunakan yaitu pembuatan jamu dan penyuluhan kepada masyarakat di daerah puskesmas tiban baru yang merupakan salah satu lokasi serius penanganan Covid19 dalam meningkatkan imunitas tubuh masyarakat. Hasil menunjukkan bahwa jamu sangat membantu meningkatkan imunitas tubuh dan semua bahan mudah didapatkan. Peserta pembuatan jamu sekitar 10 orang kader dan 5 orang mahasiswa. Pembagian sediaan jamu diberikan kepada masyarakat sekitar 30 orang di puskesmas tiban baru
\end{abstract}

\section{Pendahuluan}

Sistem imunitas di dalam tubuh manusia merupakan satu kesatuan yang kompleks dan berlapis-lapis dalam menghadapi invasi patogen yang masuk seperti bakteri, jamur, virus dan parasit. Beberapa upaya tubuh untuk melawan patogen tersebut ialah dengan adanya respon imun spesifik dan non-spesifik. Imunitas non-spesifik, seperti fagosit, sel NK dan sistem komplemen, selalu ada pada individu yang sehat dan akan dengan cepat mengeliminasi mikroba yang masuk ke jaringan pada 12 jam pertama infeksi. Berbeda dengan sistem imun non-spesifik, sistem imun spesifik mempunyai kemampuan untuk mengenal benda yang dianggap asing dan memiliki memori untuk mengatasi pajanan ulang dengan cepat (Edi Dharma dkk., 2009). 
Sistem kekebalan tubuh atau sistem imun adalah suatu sistem perlindungan tubuh terhadap pengaruh luar biologis yang dilakukan oleh sel-sel dan organ khusus pada tubuh. Sistem kekebalan ini melindungi tubuh terhadap infeksi (bakteri dan virus) serta menghancurkan zat asing lain dalam tubuh. Jika sistem kekebalan melemah maka kemampuannya melindungi tubuh juga berkurang sehingga menyebabkan agen biologis penyebab penyakit (patogen) mudah berkembang dalam tubuh (Bratawidjaja, 1996).

Pneumonia Coronavirus Disease 2019 atau COVID-19 adalah penyakit peradangan paru yang disebabkan oleh Severe Acute Respiratory Syndrome Coronavirus 2 (SARS CoV-2). Gejala klinis yang muncul beragam, mulai dari seperti gejala flu biasa (batuk, pilek, nyeri tenggorok, nyeri otot, nyeri kepala) sampai yang berkomplikasi berat (pneumonia atau sepsis). Menurut Angel, (2017) Kota Batam memiliki potensi besar dalam dunia pariwisata. Potensi pariwisata yang saat ini sedang berkembang di kota Batam adalah pariwisata kuliner dan belanja. Hal ini dapat dibuktikan dengan banyaknya pembangunan tempat makan dan mall-mall di beberapa daerah sekitar perkotaan.

Jamu adalah obat tradisional berbahan alami warisan budaya yang telah diwariskan secara turun-temurun dari generasi ke generasi untuk kesehatan. Sebagian besar masyarakat mengkonsumsi jamu karena percaya memberikan manfaat yang cukup besar terhadap kesehatan baik untuk pencegahan dan pengobatan terhadap suatu penyakit maupun dalam hal menjaga kebugaran dan kecantikan dan meningkatkan stamina tubuh. Sampai saat ini keberadaan jamu terus berkembang. Hal ini terlihat pada permintaan terhadap jamu yang terus mengalami peningkatan (Biofarmaka IPB , 2013)

Jamu merupakan salah satu warisan budaya leluhur yang dipercaya sebagai empiris memiliki manfaat dan kegunaan untuk meningkatkan imunitas tubuh (Kemenkes RI, 2015). Bahan baku yang digunakan untuk membuat jamu sebagian berasal dari tumbuhan seperti rimpang (akar - akaran), daun-daunan, kulit batang, dan buah. Sebagai golongan obat tradisional, jamu digunakan sebagian masyarakat untuk penyembuhan penyakit (Syahputra, 2014). Kunyit asam diolah dengan bahan utama kunyit dan asam. Salah satunya dapat diolah menjadi rebusan kunyit asam. Memiliki banyak manfaat bagi kesehatan dan biasanya sering digunakan dalam berbagai obat tradisional (Sina, 2012). Khasiat tanaman obat seperti kunyit 
asam dan empon-empon sangat mudah dibuat dan efektif sebagai imunitas tubuh. Berdasarkan uraian tersebut, melalui kegiatan kuliah kerja nyata untuk memberikan informasi pembuatan jamu kunyit asam dan empon-empon kepada kader Puskesmas Tiban baru yang ikut serta membantu pembuatan jamu ini dan akan dibagikan kepada masyarakat. Pembuatan jamu dan penyuluhan kepada masyarakat di daerah puskesmas tiban baru merupakan salah satu lokasi serius penanganan Covid-19 dalam meningkatkan imunitas tubuh masyarakat.

\section{Metode penelitian}

\section{Material}

Mempersiapkan bahan yang akan dibeli untuk membuat jamu empon-empon Membeli bahan ke pasar untuk membuat jamu empon empon. Pembuatan jamu empon-empon Alat yang digunakan: botol, etiket kemasan, pengaduk, kompor, panci stainless, mangkuk, gelas, piring, pisau dan talenan. Bahan yang digunakan untuk membuat jamu empon-empon: $1 / 2$ kilo jahe, $1 / 2$ kilo kunyit, 3 ons serai, 3 ons jeruk nipis, air secukupnya, dan $1 / 2$ kilo gula aren. Bahan yang digunakan untuk membuat kunyit asam yaitu: 1 ons kunyit, 6 bungkus asam jawa dan 500 gram gula aren.

\section{Rancangan Penelitian}

Pembuatan jamu empon-empon dan jamu kunyit asam dilaksanakan pada Pukul : 08.30 WIB - Selesai. Tempat pembuatan di Rumah salah satu masyarakat disekitar Puskesmas Tiban Baru dengan menerapkan protokol kesehatan. Pada hari Jumat, 19 Maret 2021

\section{Pembuatan Jamu Empon-empon}

1) Bahan pembuatan jamu empon-empon dibersihkan dan dimasukkan kedalam panci yang telah diisi air.

2) Hidupkan kompor dengan api kecil dan ditutup.

3) Sesekali jamu diaduk hingga mendidih dan menyusut.

4) Kemudian dinginkan dan campurkan jamu empon-empon dengan perasan jeruk nipis.

5) Masukkan jamu kedalam kemasan yang telah disediaan. 
JURNAL ASTA

Abdi Masyarakat Kita

Vol. 02 No. 01, Januari 2022

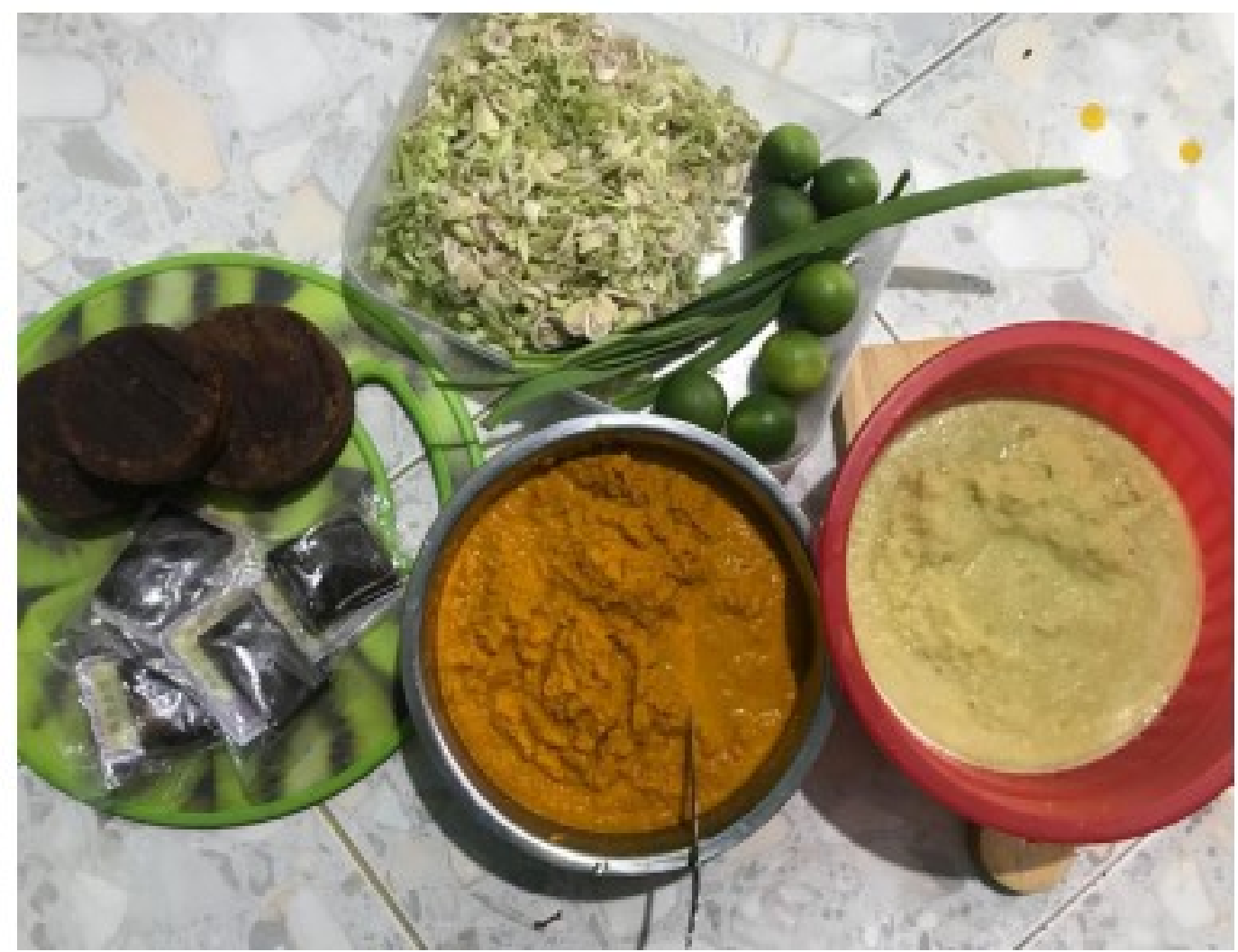

Gambar 1. Bahan pembuatan jamu empon-empon

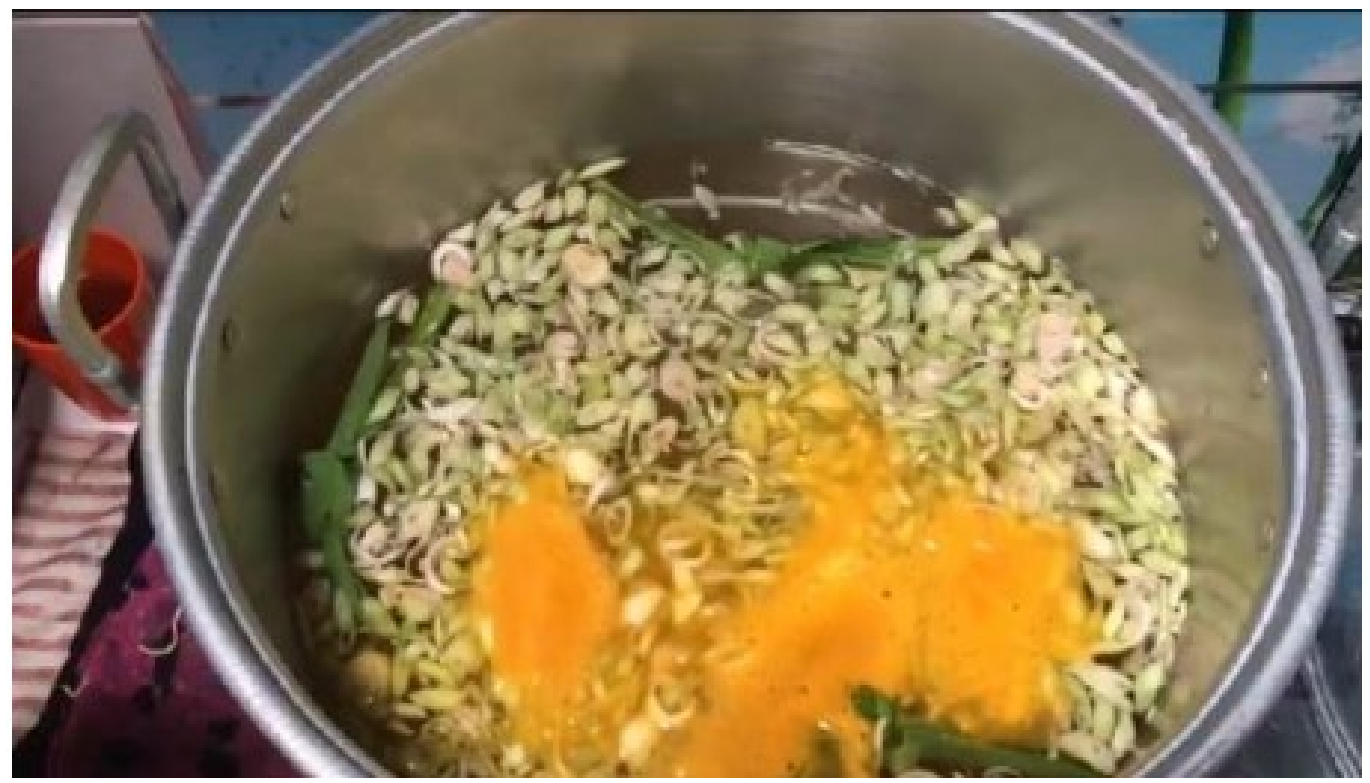

Gambar 2. Semua bahan dimasukkan kedalam panci 


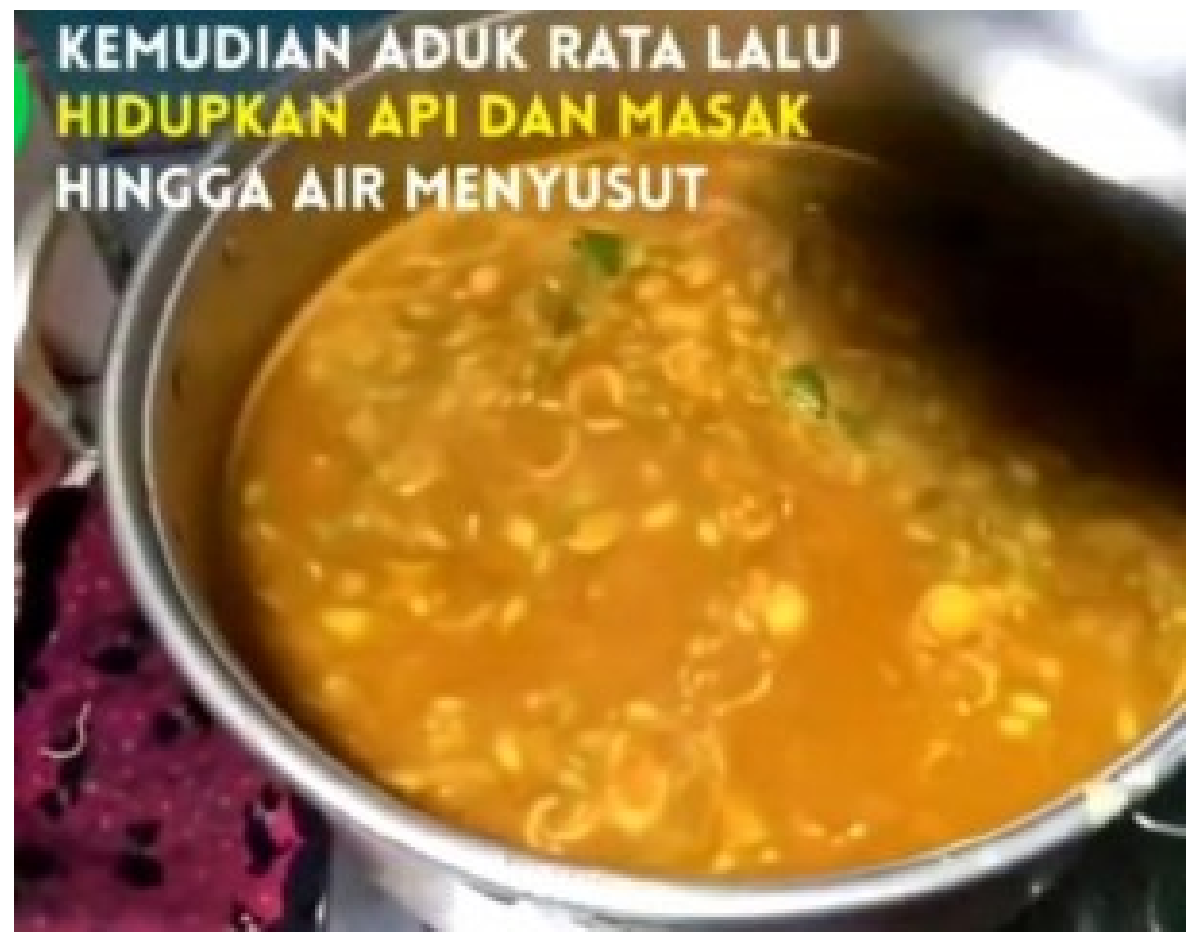

Gambar 3. Aduk dan hidupkan api hingga air menyusut

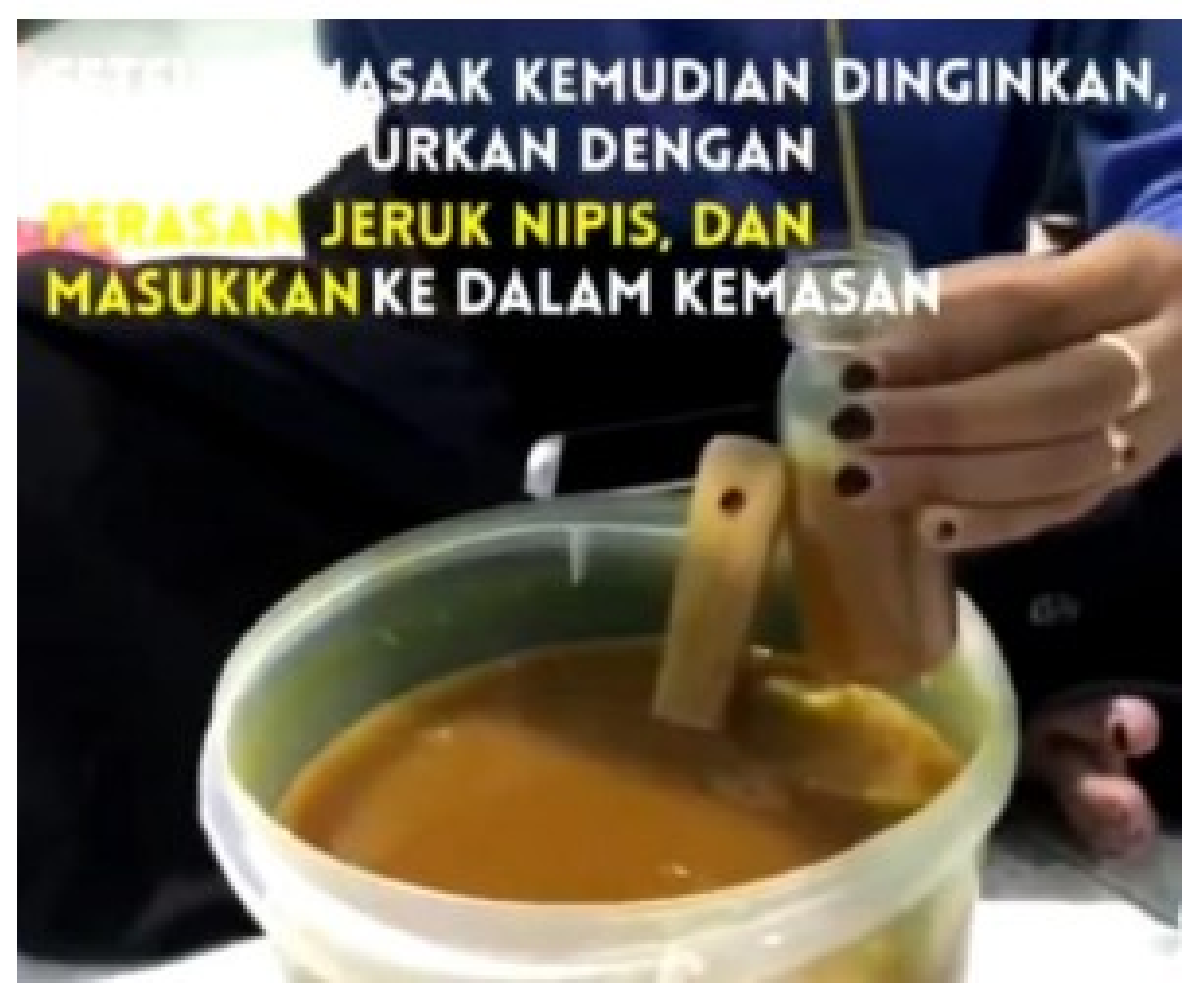

Gambar 4. Memasukkan jamu kedalam botol 
JURNAL ASTA

Abdi Masyarakat Kita

Vol. 02 No. 01, Januari 2022

\section{Pembuatan Jamu Kunyit Asam}

1) Bahan utama kunyit dibersihkan dan dipotong kecil.

2) Hidupkan kompor dengan api kecil dan ditutup.

3) Masukkan gula aren dan asam jawa kedalam panci yang telah diisi air.

4) Masukkan potongan kunyit yang telah bersih kedalam panci.

5) Tunggu hingga mendidih dan menyusut.

6) Kemudian dinginkan.

7) Masukkan jamu kedalam kemasan yang telah disediaan.

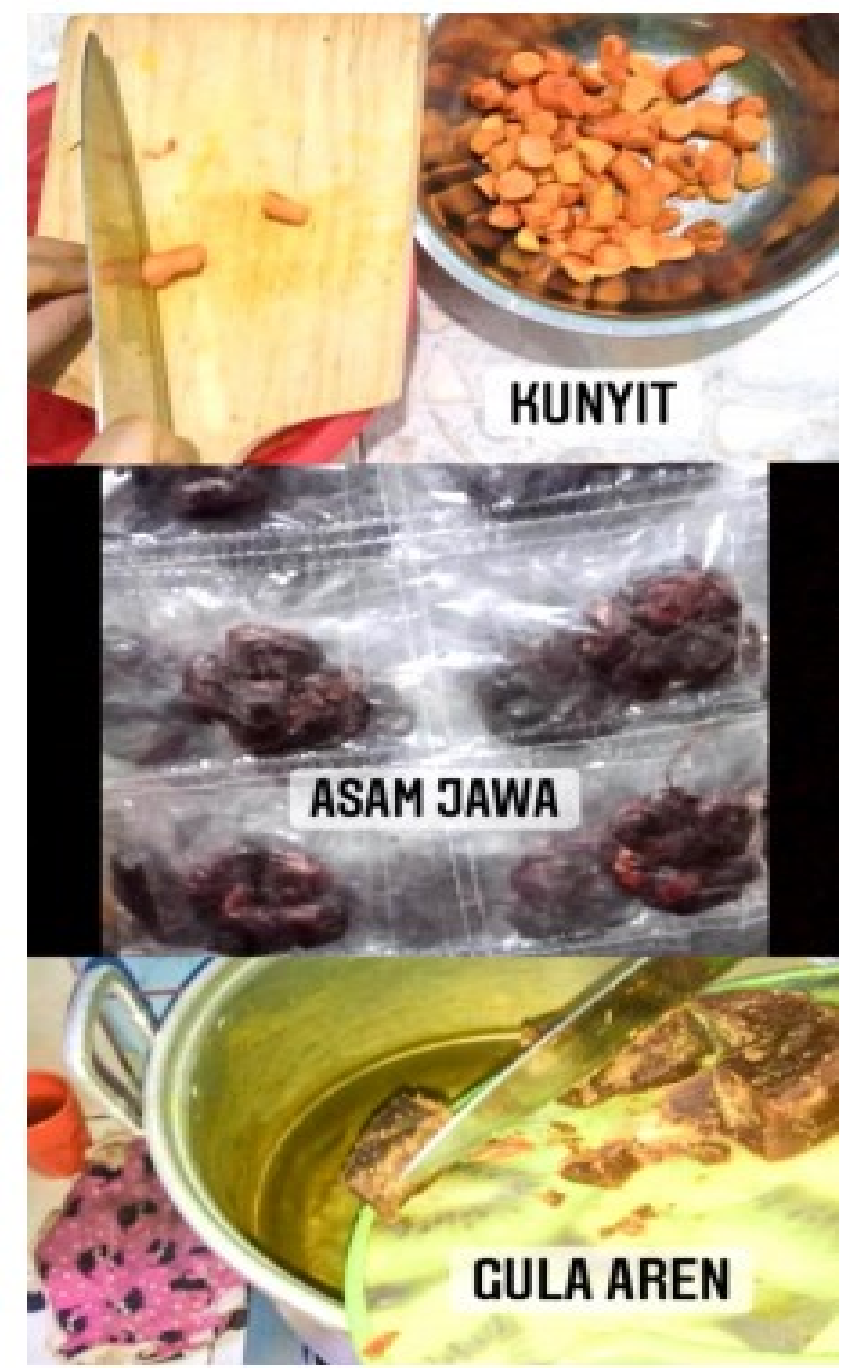

Gambar 5. Bahan pembuatan jamu kunyit asam 
JURNAL ASTA

Abdi Masyarakat Kita

Vol. 02 No. 01, Januari 2022

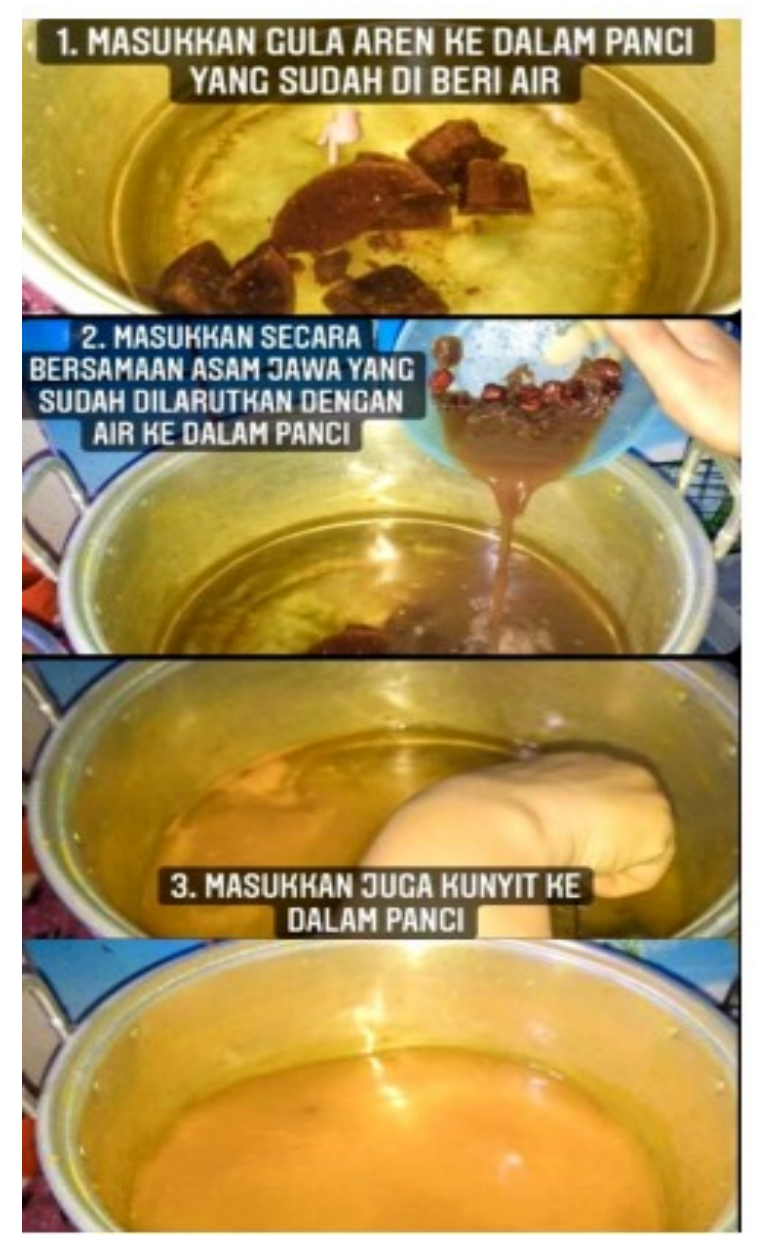

Gambar 6. Proses pembuatan jamu kunyit asam

\section{Pengemasan produk jamu empon-empon dan kunyit asam}

Jamu yang telah siap, dimasukkan kedalam botol dan diberi label.
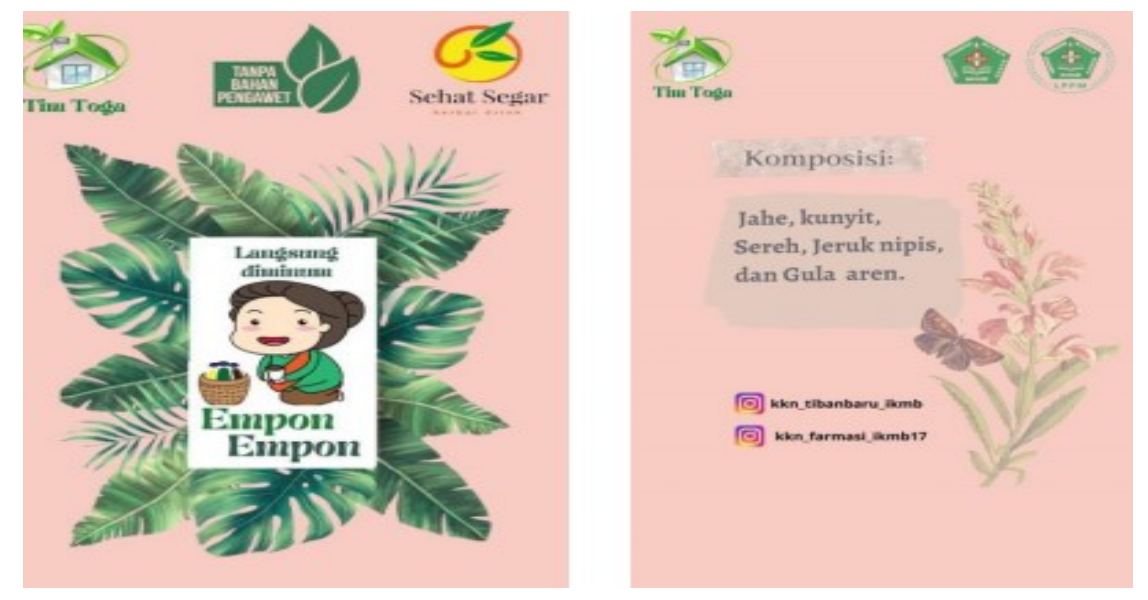

Gambar 7. Etiket Kemasan jamu empon-empon 


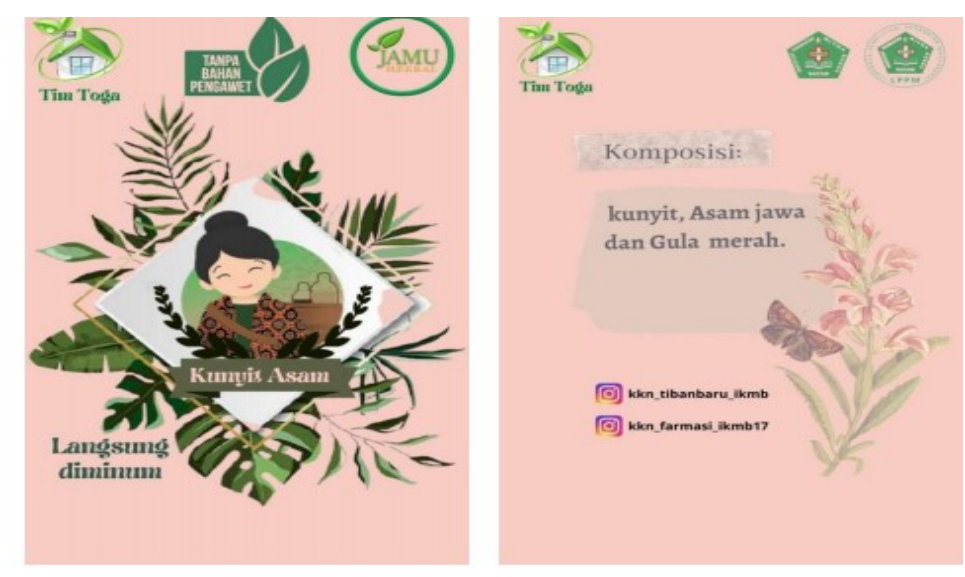

Gambar 8. Etiket kemasan jamu kunyit asam

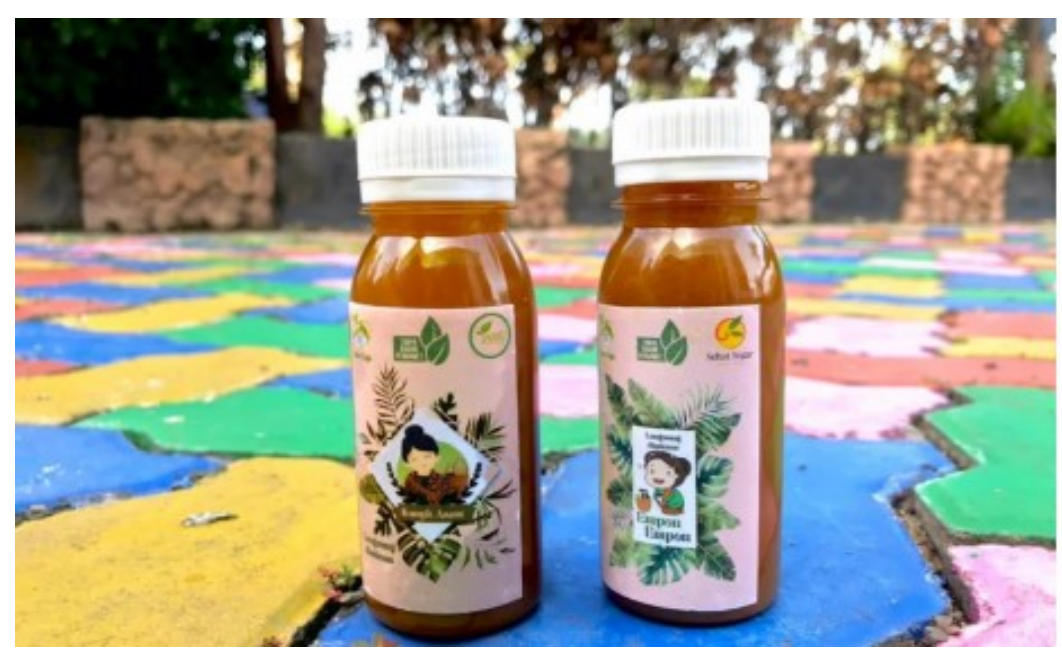

Gambar 9. Hasil jamu kunyit asam dan empon-empon homemade

\section{Tahap Pelaksanaan}

Kegiatan ini dilaksanakan pada tanggal 19 maret 2021 pada pukul 08.00-11.00 WIB. Jamu dibuat pada pagi hari di lokasi yang telah disediakan dengan protokol Kesehatan dan langsung dikonsumsi oleh para kader serta masyarakat di sekitar Puskesmas Tiban Baru. Sesuai dengan uraian tugas yang telah ditetapkan, sebelum dilakukan nya pembagian jamu, mahasiswa memberikan penyuluhan tentang manfaat dari jamu empon-empon dan jamu kunyit asam kepada staff pekerja Puskesmas Tiban Baru yang hadir sebanyak 10 orang. 
Sebelum dilakukannya pembagian jamu, mahasiswa/i memberikan penyuluhan tentang manfaat dari jamu kunyit asam kepada staff/kader dan masyarakat sekitar puskesmas tiban baru.

1) Dua hari sebelumnya, koordinator program melakukan survey tempat dan waktu untuk kegiatan yang akan dilaksanakan.

2) Satu hari sebelum kegiatan, anggota kelompok melakukan penyiapan bahan untuk membuat jamu empon-empon dan kunyit asam.

3) Pelatihan pembuatan jamu dilakukan sekitar 15 orang, yaitu bersama dengan 10 orang kader dan 5 orang mahasiswa di salah satu rumah masyarakat sekitar Puskesmas Tiban Baru, dengan protokol kesehatan yang berlaku.

4) Memberikan informasi tentang khasiat ataupun manfaat dari jamu empon-empon dan jamu kunyit asam kepada masyarakat sekitar 30 orang peserta.

5) Mahasiswa membagikan jamu empon-empon dan jamu kunyit asam serta minum jamu bersama-sama dengan staff/kader dan masyarakat sekitar Puskesmas Tiban Baru.
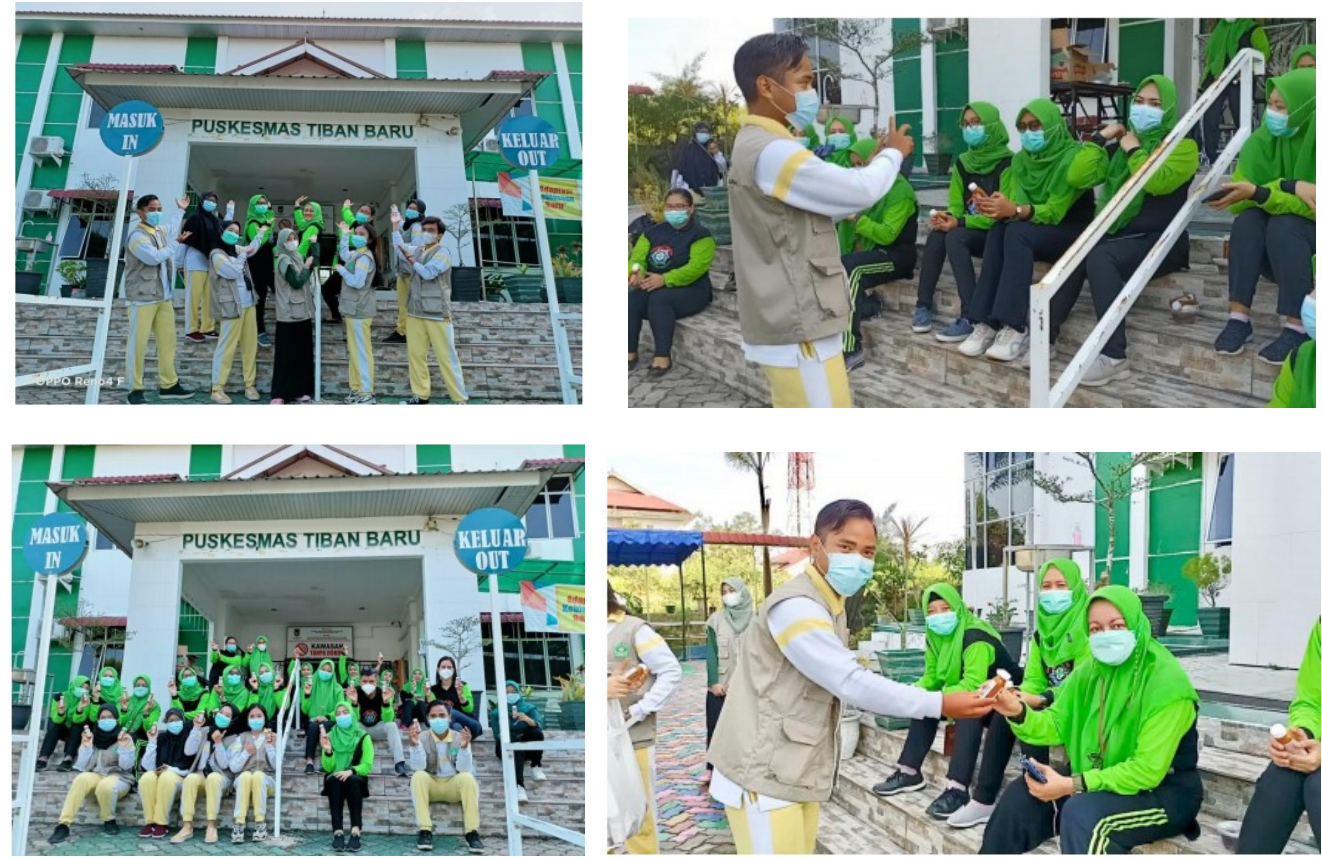

Gambar 10. Kegiatan penyuluhan pembagian jamu empon-empon dan kunyit asam 


\section{Hasil Dan Pembahasan}

Kegiatan pembagian jamu kunyit asam kepada staff/kader serta masyarakat sekitar Puskesmas Tiban Baru Kota Batam telah terlaksana pada hari Jumat, 19 Maret 2021 pada pukul 10.00 WIB - Selesai.

Pada saat kegiatan dimulai semua staff/kader yang berjumlah 10 orang serta 30 orang masyarakat sekitar Puskesmas Tiban Baru berkumpul di halaman depan Puskesmas dan mendengarkan pemateri menyampaikan materinya. Setelah kegiatan penyuluhan selesai, langsung diaksanakan pembagian jamu kunyit asam serta kegiatan minum jamu bersama. Semua staff/kader serta masyarakat sekitar Puskesmas Tiban Baru antusias dalam mengikuti kegiatan tersebut karna kebanyakan dari mereka suka minum jamu.

\section{Evaluasi}

1. Evaluasi Struktur

Staff/kader Puskesmas yang hadir pada kegiatan ini 95\%, peran serta dan tugas mahasiswa terlaksana sesuai yang direncanakan, tempat dan perlengkapan tersedia sesuai yang telah direncanakan.

2. Evaluasi Proses

Pelaksanaan kegiatan berjalan sesuai dengan yang telah direncanakan, staff/kader Puskesmas Tiban Baru selaku peserta program berperan aktif dalam memberikan informasi dan bertukar pendapat pada sesi diskusi dengan panitia dan pemateri

3. Evaluasi Hasil

Pelaksanaan program "Sosialisasi dan Pelatihan Pembuatan Jamu Kunyit Asam Sebagai Immunobooster di Masyarakat Sekitar Puskesmas Tiban Baru" berjalan dengan baik dan lancar, hasil diskusi singkat dengan peserta atau para staff/kader Puskesmas Tiban Baru menunjukkan tingkat pengetahuan masyarakat akan manfaat dari jamu empon-empon dan jamu kunyit asam baik bagi kesehatan. Dimana dari hasil penyuluhan tersebut kami sebagai tim dari mahasiswa membuatkan beberapa pertanyaan yang seluruhnya dapat dijawab oleh masyarakat puskesmas Tiban Baru dan masyarakat sangat tertarik untuk membuat sendiri jamu sederhana ini di rumah masing-masing. Sehingga, program ini dirasa sangat sesuai dilaksanakan dan diharapkan dapat memberi manfaat bagi semua 
staff/kader serta masyarakat sekitar Puskesmas Tiban Baru agar lebih menambah wawasan tentang minuman tradisional yang baik bagi kesehatan

\section{Kesimpulan}

Jamu merupakan ramuan tradisional kesehatan yang telah dikenal secara turun temurun dan digunakan oleh masyarakat Indonesia untuk memenuhi kebutuhan akan kesehatan. Jamu Empon-empon memiliki banyak sekali manfaat selain imunitas tubuh salah satunya yaitu untuk mencegah infeksi bakteri.

Jamu kunyit asam selain sebagai imunitas tubuh jamu kunyit asam juga memiliki efek antibakteri, antiradang, antioksidan, menghambat pertumbuhan sel kanker, mencegah penyumbatan pembuluh darah, dan sangat baik dikonsumsi tanpa menimbulkan efek samping berbahaya dalam penggunaannya.

Pelaksanaan kegiatan Pemberian jamu empon-empon dan jamu kunyit asam yang diberikan ke Puskesmas Tiban Baru, Kota Batam terlaksana dengan baik. Hal ini dapat terlihat dari antusiasme para staff/kader puskesmas dalam mengikuti serangkaian kegiatan tersebut.

\section{Ucapan Terimakasih}

Pada kesempatan ini, peneliti ingin mengucapkan terima kasih kepada berbagai pihak yang telah membantu terwujudnya penelitian ini :

1. Prodi Sarjana Farmasi yang sudah ikut berpartisipasi dalam kegiatan ini.

2. Bapak/Ibu tenaga kesehatan Puskesmas Tiban Baru Kota Batam.

\section{Daftar Pustaka}

Biofarmaka IPB. (2013). Quality of herbal medicine plants and traditional medicine.

Biofarmaka IPB. Curcumin Contents Antioxidant and Antilnflammatory Activities of Curcuma Xanthorrizha Roxb and Curcuma Domestica Val Promissing Lines.

Biofarmaka. (2013). Development of Partnership Model between BRC and Farmers of Biopharmaca in District Sukabumi.

Edi Dharmana, dkk. (2009). Pengaruh pemberian Tolak Angin Anak terhadap proliferasi limfosit, produksi interferon, fungsi fagositosis makrofag dan produksi ROI 
JURNAL ASTA

Abdi Masyarakat Kita

Vol. 02 No. 01, Januari 2022

Peraturan Menteri Kesehatan RI (2015). Kesehatan Lingkungan di Puskesmas. No: 13

Sina, Peter Garlans. (2012). Analisis Literasi Ekonomi. Jurnal economia, Vol. 8 Nomor 2.

Syahputra, R., Robandi, I., Ashari, M. (2014). Performance analysis of wind turbine as a distributed generation unit in distribution system. International jounal of computer science \& information technology (IJCSIT), Vol. 6, No. 3, pp. 39-56. 